\section{Oldest Pituitary Dwarf?}

Brit. med. F., 1967, 3, 842

The oldest presenting age of idiopathic pituitary dwarfism in a series reported by Albert et al. (1953) was 41. Faurbye (1946) reported the case of a 61-year-old woman and Hawley (1963) the case of a 67-year-old man. We describe the case of a man with hypopituitary dwarfism who first became ill at the age of 77 years, responded excellently to hormonal replacement therapy, and subsequently developed a carcinoma of the oesophagus.

\section{CASE REPORT}

The patient was admitted to hospital on 21 July 1965 with a history of increasing dyspnoea, swelling of the ankles, weakness, constipation, and increased sensitivity to cold. He had never shaved or experienced libido, there was no relevant past history, nor was there any family history of dwarfism. He was born on 12 February 1888 in Melbourne and had lived a life of relatively unrestricted activity successfully managing a small plant nursery for many years. In appearance he was a gnome-like man, slightly drowsy, with waxy wrinkled skin and a high-pitched voice. Body hair was absent and the testes and penis were prepubertal in size and appearance; his total height was $134 \mathrm{~cm}$., pubic-to-floor $68 \mathrm{~cm}$., and span 134 cm. Further examination showed nothing abnormal apart from a body temperature of $36.1^{\circ}$ C., a bradycardia, and sluggish tendon reflexes.

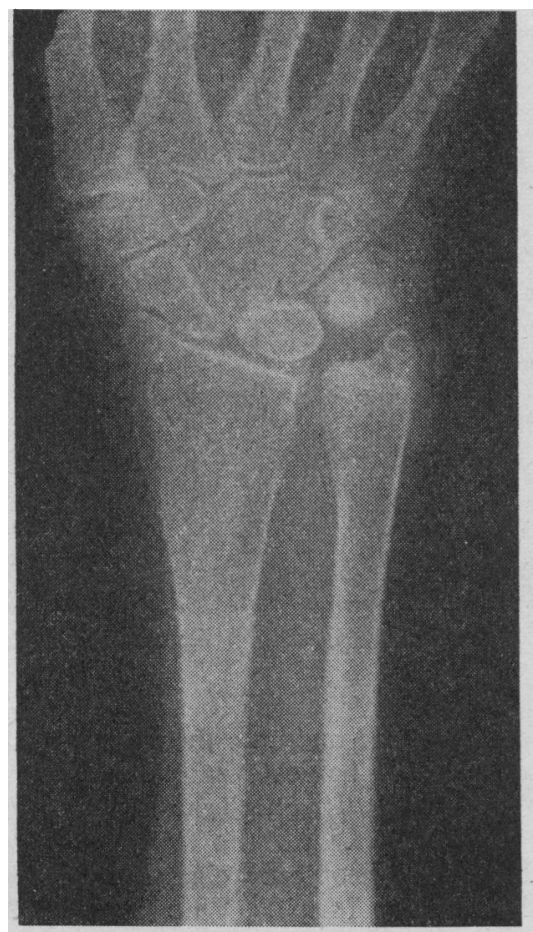

Radiograph of left wrist showing persistence of the epiphysial lines in the radius and ulna.

On admission, serum electrolytes were: sodium $121 \mathrm{mEq} / 1$. ; potassium $4.4 \mathrm{mEq} / 1$; chloride $87 \mathrm{mEq} / 1$. $\mathrm{CO}_{2}$ combining power $25 \mathrm{mEq} / \mathrm{l}$. Other relevant investigations were: serum urea $72 \mathrm{mg}$./ $100 \mathrm{ml}$.; haemoglobin $13.3 \mathrm{~g} . / 100 \mathrm{ml}$; white cell count 5,000/ cu. mm. ; E.S.R. $34 \mathrm{~mm}$. in one hour (Westergren); serum cholesterol $312 \mathrm{mg} . / 100 \mathrm{ml}$; p protein-bound iodine $2.4 \mu \mathrm{g} . / 100 \mathrm{ml}$.; 24-hour ${ }^{181}$ I thyroid retention $17 \%$; E.C.G.- - sinus bradycardia low voltages and flat or inverted $T$ waves; urinary 17 -ketosteroids $1.8 \mathrm{mg} . / 24$ hours ; 17-hydroxycorticosteroids $4.8 \mathrm{mg} . / 24$ hours; urinary gonadotrophins absent at 4.0 mouse units per day ; $\boldsymbol{x}$-ray film of skull-normal-sized sella turcica with no other abnormality ; skeletal survey-persistence of the epiphysial lines in the radius and ulna (see Fig).

Over the next two days he became stuporous, and a diagnosis of hypopituitarism with water intoxication was confirmed by a serum sodium of $102 \mathrm{mEq} / \mathrm{l}$. and a serum chloride of $74 \mathrm{mEq} / 1$. Treat- ment was begun with fluid restriction, cortisone acetate $12.5 \mathrm{mg}$. b.d., and triiodothyronine $100 \mu \mathrm{g}$./day. Within 48 hours he became restless and disorientated, with visual hallucinations and a raised temperature. Clinical examination did not reveal an infective process, and a diagnosis of an acute brain syndrome due to cortisone was made. Cortisone was decreased, fluids were further restricted, and large doses of chlorpromazine, and subsequently a combination of haloperidol (Serenace) and benzhexol (Artane), were used. Acute delirium persisted for three days, despite correction of serum electrolytes, and then gradually improved. His further course was complicated by the development of an iron-deficiency anaemia and marked peripheral oedema. The faeces were positive for occult blood, but contrast $x$-ray films at this time revealed no definite abnormality of the gastrointestinal tract. After blood transfusion there was a marked diuresis and general improvement.

At the time of his discharge from hospital, six weeks after admission, he was alert and cheerful, no abnormality was detectable in the cardiovascular or central nervous systems, and the serum electrolytes were normal. He was maintained on prednisolone $1 \mathrm{mg}$. t.d.8. and L-thyroxine $0.1 \mathrm{mg}$. a day, and remained very well until 12 months after discharge, when he complained of dysphagia, indigestion, and loss of 1 st. $(6.4 \mathrm{~kg}$.) in weight over a period of six weeks. Barium-meal examination revealed a constriction and filling defect at the lower end of the oesophagus. Biopsy showed a poorly differentiated squamous-cell carcinoma of the oesophagus invading the mucosa and muscle layers.

\section{COMMEnT}

The diagnosis of hypopituitary dwarfism in this man was established by his history and investigations. In the absence of any sign of abnormality of the pituitary fossa it would seem reasonable to assume that this is "idiopathic." It is remarkable that at least seven decades elapsed before medical attention was required for the treatment of this degree of pituitary insufficiency. It is also of interest that although there was epiphysial fusion on $x$-ray examination there was also persistence of the epiphysial lines in the radius and ulna comparable to the skeletal age standard for 18 years in the radius and 17 years in the ulna (Greulich and Pyle, 1959). The case reported by Faurbye (1946) had similar radiographs, while Hawley's (1963) case showed widespread failure of fusion of the epiphyses throughout the skeleton.

The reason for his deterioration, resulting in admission with water intoxication due to corticosteroid deficiency at this particular time, remains uncertain, but the presentation is very similar to Hawley's (1963) case. The development of an acute brain syndrome has been seen by one of us (F.I.R. M.) in several severely hypopituitary adults started on doses of cortisone greater than $25 \mathrm{mg}$./day, and it is likely that this dose was excessive in this patient.

So far as we can determine this man is the oldest patient recorded in the medical literature with idiopathic hypopituitarism and dwarfism. The development of a carcinoma in the oesophagus some 12 months after the beginning of replacement therapy with corticosteroids and thyroxine at the age of 77 years is of interest. As a barium-meal examination at the time of his original admission was normal, the possibility that there was some aetiological relation between the substitution therapy and the progress of his carcinoma deserves consideration.

We should like to thank Dr. J. H. Bolton for his kind permission to report this case.

H. L. CAPLAN, M.B., B.S., M.R.A.C.P., Registrar, Department of Psychiatry, University of Melbourne, Royal Melbourne Hospital.

F. I. R. MARTIN, M.D., M.R.A.C.P., Endocrinologist, Royal Melbourne Hospital.

\section{REFERENCES}

Albert, A., Underdahl, L. O., Greene, L. F., and Lorenz, N. (1953). Proc. Mayo Clin., 28, 698.

Faurbye, A. (1946). Acta psychiat. scand., 21, 245

Greulich, W. W., and Pyle, S. I. (1959). Radiographic Atlas of Skeletal Development of the Hand and W rist, p. 118. Stanford, Calif.

Hawley, R. R. (1963). \%. clin. Endocr., 23, 1058. 